\title{
Purification and Partial Characterization of Mammalian Cu-Dependent Amine Oxidases
}

\author{
Gunnar Houen, ${ }^{\mathrm{a}, *}$ Jytte Jørgensen, ${ }^{\mathrm{b}}$ Lise Leonardsen ${ }^{\mathrm{b}}$ and Lars-Inge Larsson ${ }^{\mathrm{b}}$ \\ anstitute of Biochemical Genetics, University of Copenhagen, $\emptyset$. Farimagsgade 2A, DK-1353 Copenhagen K., Denmark \\ and ${ }^{b}$ Department of Molecular Cell Biology, Division of Biotechnology, State Serum Institute, Building 81, Amager \\ Boulevard 80, DK-2300 Copenhagen S., Denmark
}

\begin{abstract}
Houen, G., Jørgensen, J., Leonardsen, L. and Larsson, L.-I., 1993. Purification and Partial Characterization of Mammalian Cu-Dependent Amine Oxidases. - Acta Chem. Scand. 47: 902-909.

Bovine serum amine oxidase, porcine kidney diamine oxidase and human placental and pregnancy serum diamine oxidases have been purified by affinity chromatography and ion exchange chromatography. The purified enzymes were subjected to peptide mapping studies with trypsin, $S$. aureus V8 protease and pepsin. These studies revealed similarities between the enzymes and partial sequences from the bovine serum amine oxidase were obtained. The sequences obtained showed no homology to known sequences. Immunological studies using monoclonal antibodies to the purified enzymes revealed cross reactivity between the four enzymes. These results support the view that the $\mathrm{Cu}$-dependent amine oxidases constitute a closely related group (E.C. 1.4.3.6).
\end{abstract}

Current evidence indicates that mammalian amine oxidases can be divided into two groups according to the nature of the prosthetic group: FAD-dependent (E.C. 1.4.3.4) (monoamine oxidases A and B and polyamine oxidase) and $\mathrm{Cu}$-dependent (E.C. 1.4.3.6), diamine oxidase $=$ histaminase, serum amine oxidase, and lysyl oxidase. ${ }^{1}$ While the FAD-dependent mitochondrial monoamine oxidases have been reasonably well characterized, ${ }^{2-4}$ the intracellular FAD-dependent polyamine oxidase remains less well characterized, apart from its having a relative molecular weight $\left(M_{\mathrm{r}}\right)$ of 60000 corresponding to that of the monoamine oxidases. ${ }^{5,6}$

The $\mathrm{Cu}$-dependent amine oxidases form an even less well characterized group. This seems to be due partly to the fact that these enzymes have overlapping substrate specificities and are found in both extracellular and intracellular forms and partly to the difficulties experienced in the characterization of the organic prosthetic group. ${ }^{1,7-9}$

The nomenclature reflects this situation and the enzymes are named partly according to the tissue of origin and partly according to substrate specificity. ${ }^{1}$ The best characterized enzymes are porcine kidney diamine oxidase (PKDAO), which shows high activity towards putrescine, and bovine serum amine oxidase (BSAO), which shows high activity towards benzylamine and polyamines. ${ }^{1,10-12}$ In addition to these, human pregnancy serum contains an amine oxidase (HPSDAO) with activity towards

* To whom correspondence should be adressed. putrescine, spermidine and spermine, ${ }^{13}$ human placenta contains high amounts of diamine oxidase (HPDAO) ${ }^{14}$ and the intestine is generally known to contain high amounts of diamine oxidase. ${ }^{1,10,15}$ In an attempt to characterize this group of enzymes in more detail we have purified amine oxidases from bovine serum, porcine kidney, human pregnancy serum and human placenta. The purified enzymes were used for peptide mapping studies and for raising monoclonal antibodies. These studies all showed partial identity between the enzymes from these sources.

\section{Materials and methods}

Chemicals. All chemicals used were of analytical grade or higher quality. $\mathrm{NaCl}, \mathrm{Na}_{2} \mathrm{HPO}_{4}, \mathrm{NaH}_{2} \mathrm{PO}_{4}, \mathrm{H}_{3} \mathrm{PO}_{4}$, triethylamine, methyl $\alpha$-mannopyranoside, ammonium peroxodisulfate, $\mathrm{H}_{2} \mathrm{O}_{2}(30 \%)$, glycerol, glycine, $\mathrm{MeOH}$, $\mathrm{CH}_{3} \mathrm{COOH}, \mathrm{CH}_{3} \mathrm{CN}$, and toluene were from Merck (Darmstandt, Germany). Benzylamine, putrescine $\cdot 2 \mathrm{HCl}$, spermidine $\cdot 3 \mathrm{HCl}$, spermine $\cdot 4 \mathrm{HCl}$, horseradish peroxidase, sodium dodecyl sulfate, dithiothreitol, tris(hydroxymethylamino)methane (TRIS), dansyl chloride, trypsin, pepsin, and electrophoresis low molecular weight standards were from Sigma (St. Louis, USA). Acrylamide, bisacrylamide, tetramethylethylenediamine and hydroxylapatite were from Bio-Rad (Richmond, USA).

Staphylococcus aureus V8 enzyme was from Miles (Naperville, USA), AH-Sepharose, ConA-Sepharose, and mono $\mathrm{Q}$ columns were from Pharmacia (Uppsala, 
Sweden). $\left[2,3-{ }^{3} \mathrm{H}\right]$ Putrescine was from New England Nuclear (Boston, USA). o-Phenylenediamine (OPD) was from Kem-En-Tec (Copenhagen, Denmark). DEAE cellulose was from Whatman (Maidstone, UK). Scintillation fluid was from J.T. Baker (Deventer, Holland). Trifluoroacetic acid (TFA) was from Applied Biosystems (Foster City, USA). Fetal calf serum was from Gibco (Paisley, UK). Bovine serum was from Statens Serum Institut (Copenhagen, Denmark), bovine blood from Roskilde fors $\phi$ gsslagteri (Roskilde, Denmark) and human pregnancy sera and placentas from Rigshospitalet (Copenhagen, Denmark).

Gel electrophoresis. SDS-PAGE was done by the method of Laemmli. ${ }^{16}$ Gels were of $0.75 \mathrm{~mm}$ thickness and were cast and run using a 'Mighty small' apparatus (Hoefer Scientific, San Francisco, USA).

Amino acid analysis. Samples for amino acid analysis were hydrolysed in $6 \mathrm{M} \mathrm{HCl}$ containing $0.5 \%$ phenol for $24 \mathrm{~h}$ at $110^{\circ} \mathrm{C}$. After drying, the samples were analysed on an ion-exchange column using a Waters HPLC system with post-column OPA quantitation of amino acids as described. ${ }^{17}$

Amino acid sequence analysis. Protein sequence analysis was done on a Model 477A Sequenator (Applied Biosystems, Foster City, CA, USA) with on-line analysis of phenylthiohydantoin (PTH) amino acids.

HPLC analysis of polyamines. Samples for HPLC were dansylated and analysed as described by Brossat et al. ${ }^{18}$ using a linear gradient from $50 \% \mathrm{MeOH}, 50 \% 50 \mathrm{mM}$ triethylammonium phosphate $\mathrm{pH} 4$ to $100 \% \mathrm{MeOH}$ over $15 \mathrm{~min}$ (A) or from $60 \% \mathrm{MeOH}$ to $100 \% \mathrm{MeOH}$ over $30 \mathrm{~min}$ (B). HPLC was done on a Waters system with two model 510 pumps, a model 420 -AC fluorescence detector, a 710 B WISP, a Waters Data Module, a Z-module with a $8 \mathrm{~mm} \times 10 \mathrm{~cm}$ RP -8 column, and a Waters System Controller.

Peptide mapping. Samples of $.100 \mu \mathrm{l}\left(1 \mathrm{mg} \mathrm{m}^{-1}\right)$ were incubated at $37^{\circ} \mathrm{C}$ or at room temperature with trypsin, $1: 100(\mathrm{w} / \mathrm{w}), S$. aureus $\mathrm{V} 8,1: 100(\mathrm{w} / \mathrm{w})$ or pepsin, $1: 100(\mathrm{w} / \mathrm{w})$. Reactions were terminated by addition of $10 \mu 110 \%$ TFA. Samples were then analysed on a model $130 \mathrm{~A}$ HPLC with a $2.1 \mathrm{~mm} \times 220 \mathrm{~mm} \mathrm{RP}-18$ column ( $5 \mu \mathrm{m}$ particle size, Applied Biosystems, Foster City, USA), using a linear gradient of $\mathrm{CH}_{3} \mathrm{CN}$ in $0.1 \%$ TFA: flow, $275 \mu \mathrm{l} \mathrm{min}{ }^{-1}$; column temp., $35^{\circ} \mathrm{C}$; detection, $220 \mathrm{~nm}$. V8 digests were analysed on a Waters HPLC (described above) using a $5 \mathrm{~mm} \times 100 \mathrm{~mm}$ RP18-column (10 $\mu \mathrm{m}$ particles) (Waters Novapak): flow, $500 \mu \mathrm{min}^{-1}$; column temp., $20^{\circ} \mathrm{C}$; detection, $220 \mathrm{~nm}$.

Enzyme assays. Benzylamine oxidase activity was determined as described by Tabor et al. ${ }^{19}$ using $1 \mathrm{mM}$ benzylamine in $0.1 \mathrm{M}$ phosphate buffer (PB) $\mathrm{pH} 7.2$ as the substrate. One hundred $\mu$ l of fractions to be assayed were added to $1 \mathrm{ml}$ of substrate and samples were incubated at $37^{\circ} \mathrm{C}$ for $2-16 \mathrm{~h}$. The change in absorption at $250 \mathrm{~nm}$ was measured and converted into activity using $E_{250}=$ $12.500 \mathrm{M}^{-1} \mathrm{~cm}^{-1}$ for benzaldehyde. ${ }^{20}$ One unit is defined as $1 \mu \mathrm{mol} \mathrm{min}{ }^{-1} \mathrm{mg}^{-1}$. Putrescine oxidase activity was determined by the method of Okuyama and Kobayashi ${ }^{21}$ using $1 \mathrm{mM}$ putrescine with $50 \mu \mathrm{Ci}\left[2,3-{ }^{3} \mathrm{H}\right]$ putrescine per $\mathrm{ml}$ in $\mathrm{M} \mathrm{PB} \mathrm{pH} \mathrm{7.2.} \mathrm{One} \mathrm{hundred} \mu$ l substrate $(2 \mathrm{mM})$ was mixed with $100 \mu \mathrm{l}$ of sample and incubated at $37^{\circ} \mathrm{C}$ for 2-16 h. After incubation samples were extracted with $1 \mathrm{ml}$ toluene, and after freezing on dry-ice the toluene phase was decanted into scintillation vials to which $4 \mathrm{ml}$ scintillation fluid had been added. Samples were counted in a model LS 900 scintillation counter (Beckman). Alternatively putrescine oxidase activity was determined by a coupled peroxidase assay using $1 \mathrm{mM}$ putrescine in $0.1 \mathrm{M}$ PB, pH 7.2, with $10 \mu \mathrm{g}$ HRP per $\mathrm{ml}$ and $4 \mathrm{mg}$ OPD per $50 \mathrm{ml}$. One hundred $\mu$ l of sample were incubated in $1 \mathrm{ml}$ of the assay mixture at $37^{\circ} \mathrm{C}$ for $16 \mathrm{~h}$ and the reaction was terminated by addition of $1 \mathrm{ml}$ of $1 \mathrm{M} \mathrm{H}_{2} \mathrm{SO}_{4}$. The absorption at $490 \mathrm{~nm}$ was measured and converted into activity using a standard curve for $\mathrm{H}_{2} \mathrm{O}_{2}$. Spermine oxidase activity was determined by incubating samples with $0.1 \mathrm{mM}$ spermine in $0.1 \mathrm{M} \mathrm{PB}, \mathrm{pH} 7.2$, at $37^{\circ} \mathrm{C}$ for $2-16 \mathrm{~h}$. The reaction was terminated by addition of perchloric acid and samples were dansylated and analysed by HPLC as described above.

Homogenization and extraction of placentas. One placenta was homogenized in $110.1 \mathrm{M} \mathrm{PB}, \mathrm{pH} \mathrm{7.2,} \mathrm{for} 15 \mathrm{~min}$ at $4^{\circ} \mathrm{C}$, using an Ultra Turrax (Janke und Kunkel, Breisgau, Germany) homogenizer. The homogenate was centrifuged at $8000 \mathrm{~g}$ to give 1.21 of supernatant which was used immediately.

Ammonium sulfate precipitations. Ammonium sulfate $\left(400 \mathrm{~g}^{-1}\right)$ was added and the solution stirred overnight. The precipitate was isolated by centrifugation at $13000 \mathrm{~g}$, redissolved in $0.1 \times$ the starting volume, and dialysed against $5 \mathrm{mM}$ PB pH $7.2(3 \times 51)$. The dialysed solution was centrifuged before further use.

AH-Sepharose chromatography. The column $(1 \mathrm{~cm} \times$ $20 \mathrm{~cm}$ ) was equilibrated in $5 \mathrm{mM} \mathrm{PB}, \mathrm{pH} \mathrm{7.2,} \mathrm{and} \mathrm{the}$ sample $(100-1000 \mathrm{ml})$ was pumped onto the column $\left(0.2 \mathrm{ml} \mathrm{min}^{-1}\right)$. The column was then washed with $5 \mathrm{mM}$ PB pH 7.2 until the absorption at $280 \mathrm{~mm}$ was below 0.05 and then eluted with a gradient of increasing PB concentration and finally eluted with $10 \mathrm{mM}$ octylamine in $\mathrm{PB}$ $\mathrm{pH} 7.2$.

ConA Sepharose chromatography. The column $(1 \mathrm{~cm} \times$ $10 \mathrm{~cm}$ ) was equilibrated in $0.1 \mathrm{M}$ PB pH 7.2. The sample $(50-100 \mathrm{ml})$ was pumped onto the column, which was then washed with $0.1 \mathrm{M}$ PB pH 7.2 until the absorbance at $280 \mathrm{~nm}$ was below 0.05 . Bound proteins were eluted 
with $0.3 \mathrm{M}$ methyl $\alpha$-mannopyranoside, $0.1 \mathrm{mM} \mathrm{CaCl}_{2}$ in 0.1 M.PB pH 7.2; flow, $0.2 \mathrm{ml} \mathrm{min}^{-1}$.

Mono $Q$ ion-exchange chromatography (FPLC). One ml samples were chromatographed on mono $Q$ columns $(1 \mathrm{ml})$ which were equilibrated in $50 \mathrm{mM} \mathrm{PB} \mathrm{pH} 8.0$ and eluted with a linear gradient to $1 \mathrm{M} \mathrm{NaCl}$ in $50 \mathrm{mM}$ PB pH 8.0 over $30 \mathrm{~min}$ or $1 \mathrm{~h}$; flow, $1 \mathrm{ml} \mathrm{min}^{-1}$.

DEAE-cellulose chromatography. The column $(1 \mathrm{~cm} \times$ $30 \mathrm{~cm}$ ) was equilibrated in $50 \mathrm{mM}$ TRIS pH 8.0. After loading of the sample the column was washed and then eluted with a linear gradient to $1 \mathrm{M} \mathrm{NaCl}$ in $50 \mathrm{mM}$ TRIS pH 8.0; flow, $0.2 \mathrm{ml} \mathrm{min}^{-1}$.

Hydroxylapatite chromatography. The column $(1 \mathrm{~cm} \times$ $10 \mathrm{~cm}$ ) was equilibrated in $10 \mathrm{mM} \mathrm{PB} \mathrm{pH} \mathrm{7.2.} \mathrm{After}$ loading of the sample, the column was washed with $10 \mathrm{mM}$ PB pH 7.2 and then eluted with a linear gradient up to $0.5 \mathrm{M} \mathrm{PB}$ pH 7.2; flow, $0.2 \mathrm{ml} \mathrm{min}^{-1}$.

Monoclonal antibodies: immunizations. 4-6-week-old BALB/c mice (Hvidsten, Hiller $\emptyset$, Denmark) were immunized intraperitoneally with BSAO or HPDAO. Each mouse received $50 \mu \mathrm{g}$ antigen absorbed onto $\mathrm{Al}(\mathrm{OH})_{3}$ gel $\left(6.9 \mathrm{mg} \mathrm{ml}^{-1}\right.$; State Serum Institute, Copenhagen, Denmark) per immunization. The animals were immunized 2-4 times with 14 day intervals. 2-3 days before the fusion, a $50 \mu \mathrm{g}$ booster injection was given intraperitoneally.

Fusions. Mouse myeloma cells (X63-Ag 8.653) were cultured in logarithmic phase in Dulbecco's Modified Eagle's Medium supplemented with $10 \%$ fetal calf serum (normal medium) before fusion with splenocytes isolated from immunized mice. A number of fetal calf serum batches were initially screened for benzylamine and diamine oxidase activities and a particular batch (from Biocrom KG, Darmstadt, Germany) devoid of such enzyme activity was employed throughout. Fusions were carried out at room temperature. The fused cells were dispersed in normal medium supplemented with $13.6 \mu \mathrm{g} \mathrm{ml}^{-1}$ hypoxanthine, $4.5 \mu \mathrm{g} \mathrm{ml}^{-1}$ aminopterin and $7.6 \mu \mathrm{g} \mathrm{ml}^{-1}$ thymidine (HAT medium) into 12 96-well plates (NUNC) containing 1- to 2-day-old feeder cells $\left(10^{4}\right.$ mouse peritoneal cells in $100 \mu \mathrm{l}$ HAT medium per well). Plates were incubated at $37^{\circ} \mathrm{C}$ in air $-5 \% \mathrm{CO}_{2}$ at $90 \%$ humidity. No medium replacement took place before the initial screening. Positive cultures were cloned by limiting dilution cloning. Antibody subclasses were determined using a Mono AB-ID ${ }^{\mathrm{TM}}$ Mouse EIA kit (Zymed, San Franciso, California, USA).

Ascites production. Ascites fluid was collected from pristane- (Aldrich, Steinheim, Germany) primed Balb $\mathrm{C} / \mathrm{CFI}$ mice at about 2 weeks after intraperitoneal injection of hybridoma cells. Ascites fluids were dextran sulfate-precipitated before purification of the monoclonal antibodies on protein A Sepharose columns. Antibodies were eluted with $0.1 \mathrm{M}$ citric acid, $0.5 \mathrm{M} \mathrm{NaCl}$ buffer $\mathrm{pH}$ 2.8, and neutralized with $1 \mathrm{M}$ Tris buffer, $\mathrm{pH}$ 11.0. Purified antibodies were stored in aliquots at $4{ }^{\circ} \mathrm{C}$ with $0.01 \% \mathrm{NaN}_{3}$. The purity of the antibodies was controlled by SDS-PAGE.

Immunopurification. Purified monoclonal antibodies were immobilized on divinylsulfonylagarose (Kem-EnTek, Copenhagen) by mixing $1 \mathrm{ml}$ antibody solution in $0.1 \mathrm{M} \mathrm{Na}_{2} \mathrm{CO}_{3}, \mathrm{pH} 9.0\left(2 \mathrm{mg} \mathrm{ml}^{-1}\right)$ with $1 \mathrm{ml}$ divinylsulfonylagarose which had been prewashed with $0.1 \mathrm{M} \mathrm{Na} \mathrm{CO}_{3}, \mathrm{pH}$ 9.0. After incubation overnight at $5^{\circ} \mathrm{C}, 0.2 \mathrm{ml}$ of $1 \mathrm{M}$ ethanolamine $\mathrm{pH} 9.0$ was added and incubation continued for $2 \mathrm{~h}$. The resulting resin was washed extensively with $0.1 \mathrm{M}$ PB pH 7.2 before use. Samples $(10 \mathrm{ml})$ were passed through the column which was then washed with $0.1 \mathrm{M} \mathrm{PB} \mathrm{pH} 7.2$ until $A_{280}=0$,

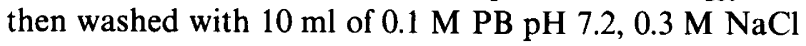
and again with $10 \mathrm{ml} 0.1 \mathrm{MPB}$. Finally bound proteins were eluted with $4 \mathrm{ml}$ of $1 \mathrm{M} \mathrm{CH}_{3} \mathrm{COOH}$. The eluate was freeze-dried and redissolved in $0.1 \mathrm{M} \mathrm{PB} \mathrm{pH} 7.2(1 \mathrm{ml})$.

Western blots. Samples were subjected to SDS-PAGE and electrotransferred to polyvinyl difluoride membranes using $25 \mathrm{mM}$ TRIS, $0.2 \mathrm{M}$ glycine $\mathrm{pH} 8.3$ as the transfer buffer $\left(0.1 \mathrm{~mA} \mathrm{~cm}^{-2}, 16 \mathrm{~h}\right)$. Membranes were blocked in skimmed milk and incubated overnight at $5^{\circ} \mathrm{C}$ with antibodies diluted $1: 500$ in skimmed milk. Incubation was continued for $1 \mathrm{~h}$ at room temperature and membranes were then washed with skimmed milk $3 \times 15 \mathrm{~min}$ and incubated $2 \mathrm{~h}$ with peroxidase-conjugated rabbit antimouse antiserum (1:500 in skimmed milk) (Dakopatts, Copenhagen). After $3 \times 15$ min washes in skimmed milk and one wash in $50 \mathrm{mM} \mathrm{NaAc}$ pH 5.0 membranes were incubated with $50 \mathrm{ml} 50 \mathrm{mM} \mathrm{NaAc}$ pH 5.0 containing $1 \mathrm{ml} \mathrm{N}, \mathrm{N}$-dimethylformamide in which $10 \mathrm{mg} \mathrm{3-amino-}$ 9-ethylcarbazole had been dissolved.

Dot blots. $10 \mu \mathrm{l}$ samples were spotted on polyvinyldifluoride membranes which were then dried, wetted with $\mathrm{MeOH}$, blocked with skimmed milk and then incubated with antibodies as described for Western blots above.

\section{Results}

Bovine serum amine oxidase was purified essentially as described ${ }^{12,20}$ by ammonium sulfate precipitation followed by affinity chromatography on aminohexylSepharose and ConA Sepharose, with additional final chromatography on a mono $\mathrm{Q}$ ion exchange column (Fig. 1). The specific activity of the purified enzyme was 0.2 units $\mathrm{mg}^{-1}$ using benzylamine as the substrate. The purified enzyme had a monomer $M_{\mathrm{r}}$ of $90 \mathrm{kDa}$ and a dimer $M_{\mathrm{r}}$ of $180 \mathrm{kDa}$ (Fig. 2). Occasionally higher $M_{\mathrm{r}}$ oligomers were also observed.

In the same way porcine kidney diamine oxidase, 


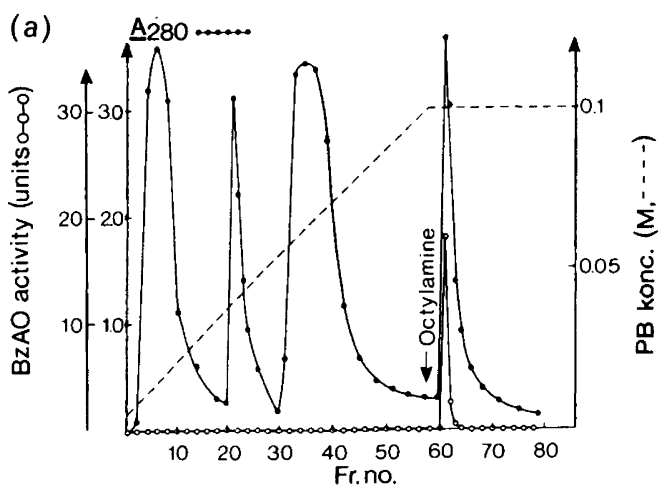

(b)

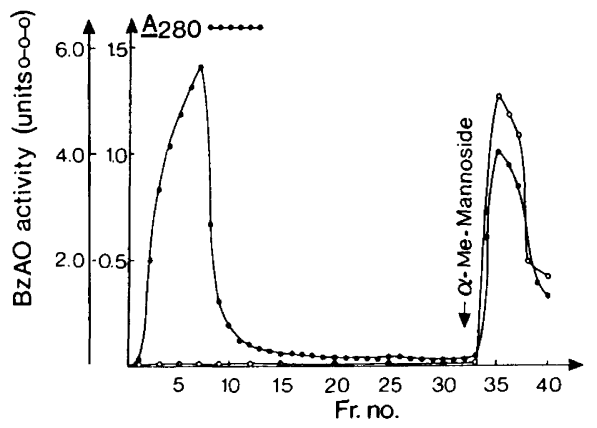

(c)

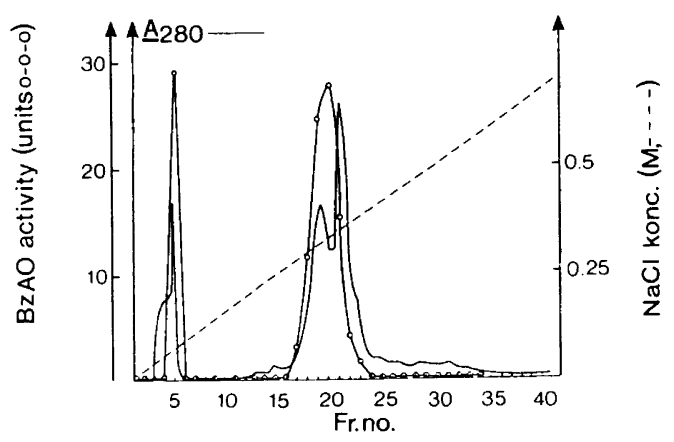

Fig. 1. (a) Chromatography of $100 \mathrm{ml}$ bovine serum on $\mathrm{AH}$-Sepharose. The sample was applied to the column $(1 \mathrm{~cm} \times 20 \mathrm{~cm})$ which was washed in $5 \mathrm{mM}$ PB, pH 7.2 eluted with a linear gradient from $5 \mathrm{mM}$ PB, pH 7.2 to $100 \mathrm{mM}$ PB, pH 7.2 and finally eluted with $100 \mathrm{mM}$ PB, pH 7.2-10 mM octylamine (arrow); flow: $0.5 \mathrm{ml} \mathrm{min}^{-1}$. Ten $\mathrm{ml}$ fractions were collected and assayed for benzylamine oxidase activity. (b) Chromatography of pooled active fractions from $\mathrm{AH}$-sepharose chromatography on ConA sepharose. Thirty $\mathrm{ml}$ were applied to a $5 \mathrm{ml}$ column which was then washed with $0.1 \mathrm{M} \mathrm{PB}, \mathrm{pH} 7.2$ and finally eluted with $0.3 \mathrm{M}$ methyl a-mannopyranoside, $0.1 \mathrm{mM} \mathrm{CaCl}{ }_{2}$ (arrow) in $0.1 \mathrm{M} \mathrm{PB}, \mathrm{pH} 7.2$; flow: $0.5 \mathrm{ml} \mathrm{min}^{-1}$. Five $\mathrm{ml}$ fractions were collected and assayed for benzylamine oxidase activity. (c) Chromatography of $1 \mathrm{ml}$ amine oxidase from ConA sepharose on a mono $Q$ column. After application of the sample, the column was eluted with a linear gradient from $50 \mathrm{mM}$ PB, pH 7.2 to $50 \mathrm{mM}$ PB, pH 7.2, $1 \mathrm{M} \mathrm{NaCl}$ over $60 \mathrm{~min}$; flow: $0.5 \mathrm{ml} \mathrm{min}^{-1}$. Half-millilitre fractions were collected and assayed for benzylamine oxidase activity.

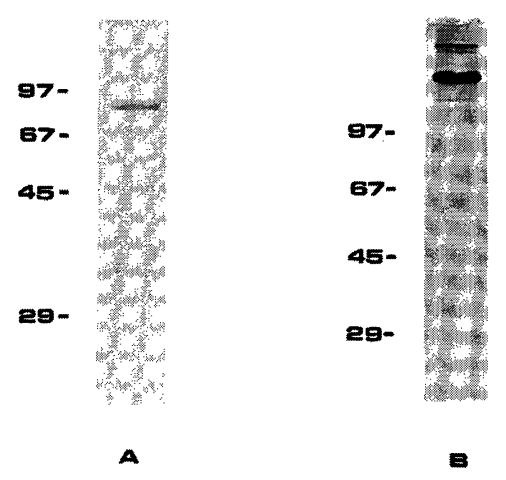

Fig. 2. SDS-PAGE analysis of purified bovine serum amine oxidase. Samples were boiled in electrophoresis sample buffer (1:1) with $40 \mathrm{mM}$ DTT (A) or without DTT (B) and analysed on $11 \%(\mathrm{~A})$ or $10 \%(\mathrm{~B})$ gels.

human placental diamine oxidase and human pregnancy serum diamine oxidase were purified. All the enzymes showed monomer and dimer $M_{\mathrm{r}} \mathrm{s}$ of $90 \mathrm{kDa}$ and $180 \mathrm{kDa}$, respectively (not shown).

The purified enzymes were subjected to amino acid analysis and peptide mapping studies, in order to assess the relationship between the enzymes and to obtain amino acid sequence information.

All of the enzymes were resistant to cleavage with trypsin as also described recently by Janes et al. ${ }^{9}$ and released only a few hydrophilic peptides. However, similar profiles were seen in HPLC chromatograms of the limited trypsin digests (Fig. 3). BSAO was the enzyme most susceptible to trypsin and V8 treatment and could be digested more extensively in the presence of $20 \%$ organic solvent resulting in the profiles shown in Fig. 10. Selected peaks from the chromatograms were subjected to automated Edman sequencing whereby the sequences in Table 1 were

Table 1. Amino acid sequences of peptides derived from BSAO. ${ }^{a}$

\begin{tabular}{lll}
\hline septide & Enzyme & Sequence \\
\hline 1 & $T$ & AFsLG3 \\
2 & $\mathrm{~T}$ & ALDPADWTVOK \\
3 & $\mathrm{~T}$ & STWFGIYYXITK \\
4 & $\mathrm{~T}$ & EGQDAGSQEINPLAQL \\
5 & $\mathrm{~T}$ & NQNDPWTPTVDFSDFINXETIAGK \\
6 & $\mathrm{~T}$ & VDLDVGGLENWVWAEDMAFVPTAIP \\
7 & V8 & XQXAGSXE \\
8 & V8 & NWVWAE \\
9 & V8 & MAFVPTAIpNSe
\end{tabular}

a Peptides from HPLC were applied directly to the Polybrenecoated glass filter and subjected to automated Edman degradation. Sequences in the tryptic peptides which were also found in the $S$. aureus V8 peptides are italicized. Capital letters indicate that the residue was unambiguously identified. Lower-case letters indicate that the residue was identified with a high degree of certainty. $x$ denotes positions where no residue was identified. 


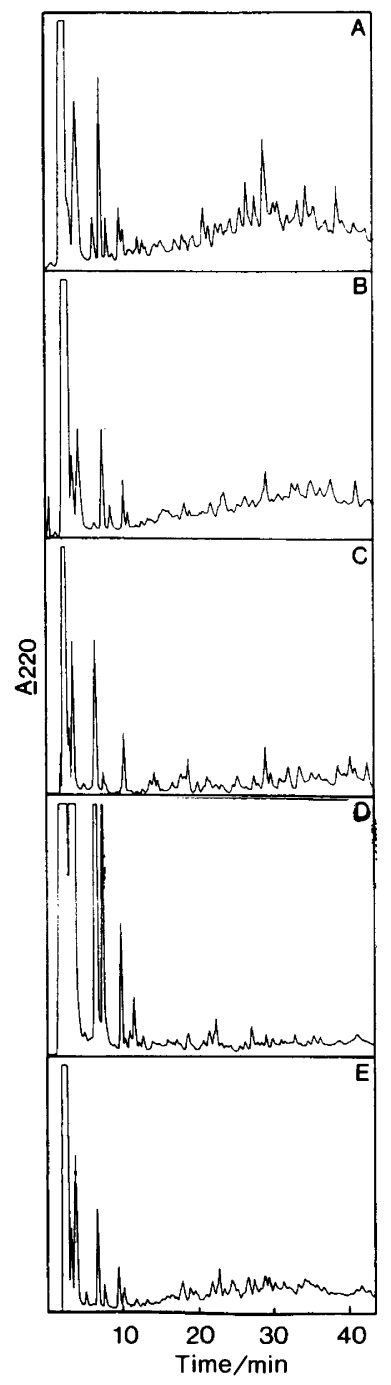

Fig. 3. HPLC profiles of limited tryptic digests of purified amine oxidases: A, BSAO; B, PKDAO; C, HPSDAO; D, HPDAO 1; E, HPDAO 2. The samples $\left(100 \mu \mathrm{l}, 1 \mathrm{mg} \mathrm{ml}^{-1}\right)$ were incubated with trypsin $1: 1000(w: w)$ at $37^{\circ} \mathrm{C}$ overnight. The reaction was stopped by addition of $10 \mu \mathrm{l} 10 \%$ TFA. Hundred $\mu \mathrm{l}$ aliquots were analysed on a $\mathrm{C}-18$ column $(2.1 \mathrm{~mm} \times 220 \mathrm{~mm})$ eluted with a gradient of $\mathrm{CH}_{3} \mathrm{CN}$ in $0.1 \%$ TFA

Table 2. Cross-reactivity table for monoclonal antibodies against amine oxidases tested against purified amine oxidases by dot blot and Western blot. ${ }^{a}$

\begin{tabular}{|c|c|c|c|c|}
\hline \multirow[b]{2}{*}{ Antibody } & \multicolumn{4}{|c|}{ Enzyme } \\
\hline & BSAO & HPSDAO & HPDAO & PKDAO \\
\hline $\begin{array}{ll}1 & \text { BSAO } 10 \text { D9-4 } \\
2 & \text { BSAO } 7 \text { C6-2 } \\
3 & \text { BSAO } 10 \text { E5-3 } \\
4 & \text { HPDAO } 40-6 \\
5 & \text { HPDAO } 40-2 \\
6 & \text { HPSDAO 869-3 } \\
7 & \text { Control mab 8DY }\end{array}$ & $\begin{array}{l}+++ \\
+++ \\
+++ \\
+ \\
++ \\
+ \\
+\end{array}$ & $\begin{array}{l}+ \\
+ \\
++ \\
+ \\
+++ \\
+++ \\
+\end{array}$ & $\begin{array}{l}+ \\
+ \\
+ \\
+++ \\
+++ \\
+ \\
+\end{array}$ & $\begin{array}{l}++ \\
++ \\
++ \\
+1- \\
+1- \\
+1- \\
-\end{array}$ \\
\hline
\end{tabular}

${ }^{a}+++$, strong reactivity; ++ , medium reactivity; + , weak reactivity; - , no reactivity. obtained. The enzymes were susceptible to degradation with pepsin (Fig. 4) but the resulting peaks isolated from the HPLC were, in most cases, found to contain several coeluting peptides, and were not suitable for direct sequence analysis.

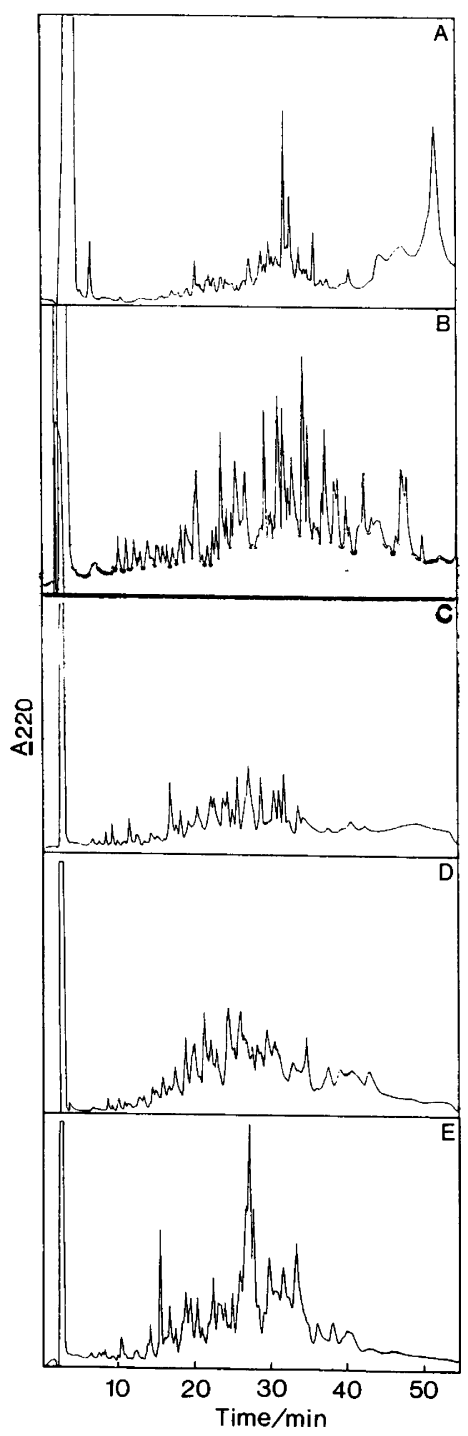

Fig. 4. HPLC profiles of various proteolytic digests of purified amine oxidases: A BSAO $(300 \mu \mathrm{g}$ in $300 \mu \mathrm{l}$ PB pH 7.2 with $10 \% \mathrm{MeOH}$ ) digested with $S$. aureus $\mathrm{V} 8$ protease $(1: 100 w: w)$ in the presence of organic solvent $(10 \%$ $\mathrm{MeOH}$ ). The reaction was carried out overnight at room temp. and was terminated by addition of $10 \mu \mathrm{l} 10 \%$ TFA. Hundred $\mu \mathrm{l}$ were analysed on a $0.5 \mathrm{~cm} \times 10 \mathrm{~cm}$ RP-18 column (Waters, Novapak). B, BSAO digested extensively with trypsin. A hundred $\mu \mathrm{g}$ in $100 \mu \mathrm{l} \mathrm{PB} \mathrm{pH} 7.2$ were treated with trypsin $(1: 10 \mathrm{w}: \mathrm{w})$ at room temp. for $10 \mathrm{~h}$. The reaction was stopped by addition of $10 \mu \mathrm{l} 10 \%$ TFA. A hundred $\mu \mathrm{l}$ of the reaction mixture were analysed on a $2.1 \mathrm{~mm} \times 220 \mathrm{~mm}$ RP18 column. C-E, digestions of BSAO (C), HPSDAO (D) and $\mathrm{HPDAO}(\mathrm{E})$ with pepsin analysed by HPLC as in $B$. Samples were incubated with pepsin $(1: 100, w: w)$ for $1 \mathrm{~h}$ at $37^{\circ} \mathrm{C}$. Reactions were stopped by addition of $10 \%$ TFA and the reaction mixture was injected into the HPLC. 


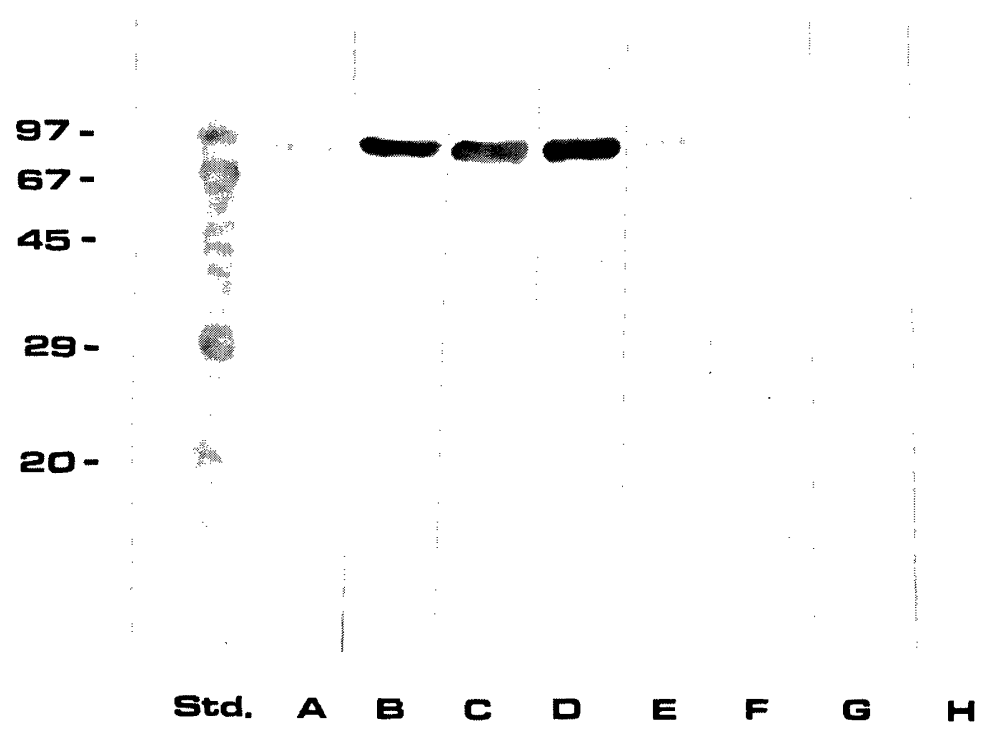

Fig. 5. Western blots using BSAO purified by monoclonal antibody $10 \mathrm{D} 9-4$ and incubated with monoclonal antibodies: A, coomassie stained strip; B, 10 D9-4; C, 7C6-2; D, 10E5-3; E-F, anti-HPDAO; E, Hyb 40-6; F, Hyb 40-2; G-H, anti HPSDAO; G, HPSDAO 869-3; H, HPSDAO 8DY.

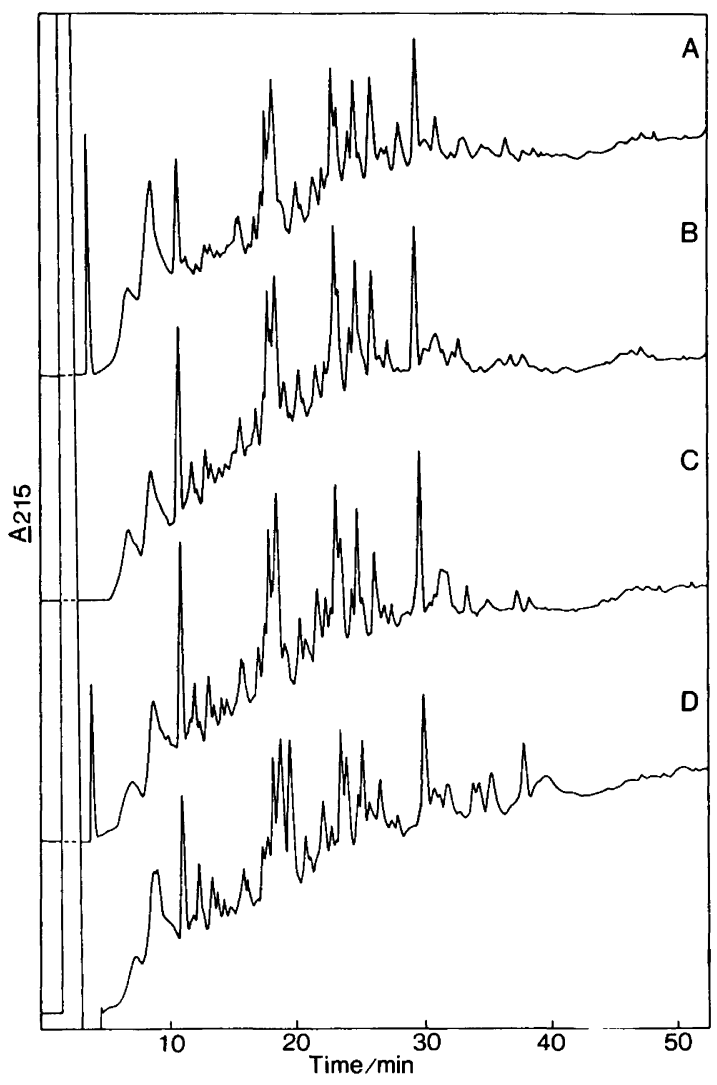

Fig. 6. Peptide maps of immunopurified BSAO (A), PKDAO (B), HPSDAO (C), HPDAO (D). Individual peaks from the chromatograms were collected for subsequent sequence analysis.
The purified bovine serum amine oxidase, human placental and human pregnancy serum diamine oxidases were used for raising monoclonal antibodies, which were in turn used for purifying amine oxidases from the various sources. The immunopurified enzymes were used for studying cross-reactivity between the various monoclonal antibodies. In Fig. 5 are shown results of Western blots using bovine serum amine oxidase purified by one monoclonal antibody (10 D9-4) and subsequently incubated with monoclonal antibodies to BSAO, HPDAO and HPSDAO. As seen the monoclonal antibodies to BSAO all cross-reacted strongly with the BSAO purified by monoclonal antibody $10 \mathrm{D} 9-4$ whereas monoclonal antibodies to HPDAO cross reacted more weakly and one monoclonal antibody to HPSDAO cross-reacted with BSAO while one monoclonal antibody to HPSDAO did not show cross reactivity. Extending these studies to amine oxidases purified by the monoclonal antibodies from the four different sources and using both Western blots and dot blots the cross reactivity results shown in Table 2 were obtained. Generally, all the antibodies cross-react with all four enzymes, but the strongest crossreactivity is seen between BSAO and PKDAO and between HPDAO, BSAO and HPSDAO. Peptide mapping studies using the immunopurified enzymes are shown in Fig. 6. In these studies the enzymes were digested with trypsin in the presence of $20 \% \mathrm{MeOH}$ since the addition of organic solvent had previously been found to improve the digestion of the bovine serum amine oxidase. Although relatively few peptides were released by trypsin digestion, it can be concluded that the peptide maps are very similar. 


\section{Discussion}

$\mathrm{Cu}$-containing amine oxidases have previously been purified and characterized from porcine and human kidney, human placenta, porcine and bovine serum and human pregnancy serum. ${ }^{1,7-10,12,20,22-24}$ These studies showed that the $\mathrm{Cu}$-containing amine oxidases have similar compositions with a monomer $M_{\mathrm{r}}$ of $90 \mathrm{kDa}$, and a dimer $M_{\mathrm{r}}$ of $180 \mathrm{kDa}$ and form multimers of higher $M_{\mathrm{r}}$. The $\mathrm{Cu}$ content is one $\mathrm{Cu}$ atom per monomer and the content of organic prosthetic group is a minimum of one per dimer. The enzymes contain about $10 \%$ carbohydrate and have isoelectric points between 4.5 and 6.5. In these studies, where the enzymes from different tissues and body fluids within the same species were compared, the enzymes were found to be identical with respect to the properties compared, i.e., substrate specificites, $M_{\mathrm{r}}$, immunological properties, and structure. A comparison of published values for amino acid composition of PKDAO, HPSDAO, PSAO and BSAO showed a close relationship between the enzymes (not shown), in line with the above results. In the present study, the four amine oxidases could be purified by ammonium sulfate precipitation, AH-Sepharose chromatography, ConA Sepharose chromatography and ion-exchange chromatography. The purified proteins showed bands of $M_{\mathrm{r}} 90000$ and 180000 upon SDS-PAGE, corresponding to the enzyme monomer and dimer, respectively.

The four enzymes, although resistant to proteolytic digestion, showed similar peptide patterns in HPLC chromatograms of tryptic digests, although differences in the peptide patterns were also found. The enzymes were susceptible to pepsin digestion. The bovine enzyme could be more extensively digested by trypsin and $S$. aureus V8 enzyme in the presence of organic solvent and several peptides were isolated and sequenced. The sequences obtained showed no homology to known sequences. The purified enzymes were also used for obtaining mouse monoclonal antibodies. Most of the antibodies showed cross-reactivity with the different purified enzymes. Together these results indicate that the $\mathrm{Cu}$-amine oxidases form a closely related group of enzymes (E.C. 1.4.3.6). Determination of the exact number of enzymes, however, must await further studies, but it seems clear that a close relationship exists between the enzymes, with differences in structure reflecting the differences in substrate specificity. ${ }^{1}$

Acknowledgments. The Danish Cancer Society, the Lundbeck Foundation and the Research Center for Medical Biotechnology are thanked for partial financial support. Inge Steiness is thanked for secretarial assistance and Lis Lehfelt for drawings. Chief midwife Marie Østergård and the staff of the gynaecological departments, Rigshospitalet, are thanked for collecting placentas and pregnancy sera.

\section{References}

1. Mondovi, B., Ed. Structure and Functions of Amine Oxidases, CRC PRESS, Boca Raton. Florida, USA 1985.

2. Bach, A. W. J., Lan, N. C., Johnson, D. L., Abell, C. W., Bembenek, M. E., Kwan, S.-W., Seeburg, P. H. and Shih, J. C. Proc. Natl. Acad. Sci. USA, 85 (1988) 4934.

3. Powell, J. F., Hsu, Y.-P. P., Weyler, W., Chen, S., Salach, I., Andrikopoulos, K., Mallet, I. and Breakefield, X. O. Biochem. J. 259 (1989) 407.

4. Weyler, W. Biochem. J. 260 (1989) 725.

5. Höltta, E. Biochemistry 16 (1977) 91.

6. Tsukada, T., Furusako, S., Maekawa, S., Hibasami, H. and Nakashima, K., Int. J. Biochem. 20 (1988) 695.

7. Hartmann, C. and Klinman, J. P. J. Biol. Chem. 262 (1987) 962.

8. van der Meer, R. A., Wassenaar, P. D., van Brouwershaven, J. H. and Duine, J. A. Biochem. Biophys. Res. Commun. 159 (1989) 726.

9. Janes, S. M., Mu, D., Wemmer, D., Smith, A. J., Kaur, S., Maltby, D., Burlingame, A. L. and Klinman, J. P. Science 248 (1990) 981.

10. Seiler, N. In: McCann, P. P., Pegg, A. E. and Sjoerdsma, A., Eds., Inhibition of Polyamine Metabolism, Academic Press, San Diego USA, 1987, p. 49.

11. Bardsley, W. G., Hill, C. M. and Lobley, R. W. Biochem. J. 117 (1970) 169.

12. Mondovi, C., Turini, P., Befani, O. and Sabatini, S. In: Tabor, H. and Tabor, C. W., Eds., Methods in Enzymology, Vol. 94, Academic Press, London 1983, p. 314.

13. Gahl, W. A. and Pitot, H. C. Life Sci. 29 (1981) 2177.

14. Bardsley, W. G., Crabbe, M. J. C. and Scott, I. V. Biochem. J. 139 (1974) 169.

15. Bieganski, T. Acta Physiol. Pol. 34 (1983) 139.

16. Laemmli, U. K. Nature (London) 227 (1979) 680.

17. Barkholt, V. and Jensen, A. L. Anal. Biochem. 177 (1989) 318.

18. Brussat, B., Straczek, J., Belleville, F. and Nabet, P. J. Chromatogr. 177 (1983) 87.

19. Tabor, C. W., Tabor, H. and Rosenthal, S. M. J. Biol. Chem. 208 (1954), 645.

20. Turini, P., Sabatini, S., Befani, O., Chimenti, F., Casanova, C., Riccio, P. L. and Mondovi, B. Anal. Biochem. 125 (1982) 294.

21. Okuyama, T. and Kobayashi, Y. Arch. Biochem. Biophys. 95 (1961) 242.

22. Zeller, E. A. In: Boyer, P. D., Lardy, H. and Myrbäck, K., Eds., The Enzymes, Vol. 8, Academic Press, London 1963, p. 313.

23. Blaschko, H. In: Boyer, P. D., Lardy, H. and Myrbäck, K., Eds., The Enzymes, Vol. 8, Academic Press, London 1963, p. 337.

24. Buffoni, F. Pharmacol. Rev. 18 (1966) 1163.

25. Yasunoby, K. T., Ishizaki, H. and Minamiura, N. Mol. Cell. Biochem. 13 (1976) 3.

26. Kluetz, M. D. and Schmidt, P. G. Biochem. Biophys. Res. Commun. 76 (1977) 40.

27. Rinaldi, A., Vecchini, P. and Floris, G. Preparative Biochem. 12 (1982) 11.

28. Amicosante, G., Oratore, A., Crifo, C. and Finazzi-Agró, A. Experientia 40 (1984) 1140.

29. van der Meer, R. A., Jongejan, J. A., Frank, J. and Duine, J. A. FEBS Lett. 206 (1986) 111.

30. Dooley, D. M., McGuirl, M. A., Peisach, J. and McCracken, J. FEBS Lett. 214 (1987) 274.

31. Shah, M. A. and Ali, R. Biochem. J. 253 (1988) 103.

32. Suzuki, O. and Matsumoto, T. Biogenic Amines 4 (1987) 237.

33. Lin, C.-W., Kirley, S. D. and St. Pierre, M. Oncodevelopm. Biol. Med. 2 (1981) 267.

34. Crabbe, M. J. C., Waight, R. D., Bardsley, W. G., Barker, 
R. W., Kelly, I. D. and Knowles, P. F. Biochem. J. 155 (1976) 679.

35. Baylin, S. B. Proc. Natl. Acad. Sci. USA 74 (1977) 883.

36. Smith, J. K. Biochem. J. 103 (1967) 110.

37. Baylin, S. B. and Margolis, S. Biochim. Biophys. Acta 397 (1975) 294.

38. Tufvesson, G., Scand. J. Clin. Lab. Invest. 38 (1978) 473.

39. Buffoni, F. and Blaschko, H. Proc. R. Soc. London, Ser. B $161(1964) 153$.

40. Williams, T. J. and Falk, M. C. J. Biol. Chem. 261 (1986), 15949.
41. Knowles, P. F., Pandeya, K. B., Rins, F. X., Spencer, C. M., Moog, R. S., McGuirl, M. A. and Dooley, D. M. Biochem.J. 241 (1987) 603.

42. Yasunobu, K. and Smith, R. A. Methods Enzymol. 17 (1971) 698.

43. Lobenstein-Verbeek, C. L., Jongejan, J. A., Frank, J. and Daine, J. A., FEBS Lett. 170 (1984) 305.

44. Moog, R. S., McGuirl, M. A., Cote, C. E. and Dooley, D. M. Proc. Natl. Acad. Sci. USA 83 (1986) 8435.

Received December 22, 1992. 